\title{
Art Spiegelman's 'Little Signs of Passion' and the emergence of hard-core pornographic feature film
}

\author{
Paul Williams
}

In 1973 Bob Schneider and the underground comix ${ }^{1}$ creator Art Spiegelman compiled Whole Grains: A Book of Quotations. One of the aphorisms included in their book came from D. H. Lawrence: 'What is pornography to one man is the laughter of genius to another'. ${ }^{2}$ Taking a cue from this I will explore how Spiegelman's comic 'Little Signs of Passion' (1974) turned sexually explicit subject matter into an exuberant narratological experiment. This three-page text begins by juxtaposing romance comics against hard-core pornography, ${ }^{3}$ the former appearing predictable and artificial, the latter raw and shocking, but this initial contrast breaks down; rebutting the defenders of pornography who argued that it represented a welcome liberation from repressive sexual morality, 'Little Signs of Passion' reveals how hard-core filmmakers turned fellatio and the so-called money shot (a close-up of visible penile ejaculation) into standardised narrative conventions yielding lucrative returns at the box office. This essay then considers the ways 'Little Signs of Passion' intervened in debates about the gendering of pleasure in pornography, arguing that the character Bernie alerts readers to the ways that hard-core filmmaking assuaged heterosexual masculine anxiety towards the phallus. By showing that hard-core films were not radical in terms of narrative structure or the dominant viewing position they set up, 'Little Signs of Passion' can be seen as a challenge to the counterculture's celebration of pornography's politically subversive qualities. Further, while 'Little Signs of Passion' endorses a view of romance comics as following repetitive narrative conventions, Spiegelman seems to greatly admire the genre's ability to encode sexual desire in visual metaphors, and he builds his comic around one such image, the red paint that spills onto the sidewalk. Accordingly, this essay ends by reading 
'Little Signs of Passion' as a monument to the enduring visual power of romance comics, something that makes Spiegelman's comic stand out from other underground parodies of the genre.

Spiegelman is best known for Maus (1980-1991), a graphic narrative about his father's experiences in the Holocaust. Given its centrality to the development of long-form comics, and its widespread public recognition, Maus has attracted the majority of research into Spiegelman's work, with recent scholarship extending to In the Shadow of No Towers (2004), an account of 9/11 and its aftermath. When academics have written on Spiegelman's comics from the 1970s they have been primarily interested in how two texts from 1972 ('Prisoner on the Hell Planet' and 'Maus') relate to Maus. ${ }^{4}$ Exceptions to this trend include Gene Kannenberg, Jr's 2002 doctoral thesis, Bill Kartalopoulos's online essay 'Comics as Art: Spiegelman's Breakdowns' (2005), and Philip Smith's Reading Art Spiegelman (2016), ${ }^{5}$ the latter of which has a chapter on Spiegelman's first book collection Breakdowns (1977). ${ }^{6}$ None of these engage with 'Little Signs of Passion' at length (despite it being reprinted in Breakdowns) although Kartalopoulos's insights are relevant and I return to them below. Smith aligns Breakdowns with the counterculture and understands its stylistic innovations as a critique of widely held notions of reason and sanity, but I will argue Spiegelman was highly sceptical of one aspect of the counterculture, namely freedom of sexual expression.

In the mid-1970s Spiegelman produced 'comics in which the narrative underpinnings of comics storytelling become story experiences themselves' ${ }^{7}$ and the very title of Breakdowns 'connotes the very constructive activity of taking something apart $[\ldots]$ the better to engage with the panels even more microanalytically than usual' ${ }^{8}$ In 1975 film critic Michael Reynolds reviewed 'Little Signs of Passion' as 'a strip about processes, more about the "how" than the "why" of what transpires on the page'. Spiegelman 'has rethought the possibilities inherent in the comic strip [...] and filtered it through the structural concerns that 
have dominated the arts for the past few years, most especially in independent film making'. ${ }^{9}$ Reynolds observed the title's allusion to Ken Jacobs's avant-garde film Little Stabs at Happiness (1963); Jacobs was Spiegelman's 'mentor and irascible best friend' ${ }^{10}$ Stretches of Little Stabs at Happiness are unedited, the voiceover is barely audible, and shots can be difficult to discern due to disorientating close-ups and sunlight reflected into the camera lens. By removing the conventions that make watching a film as smooth and continuous a process as possible, Jacobs reminds viewers that filmmaking's norms of narrative storytelling have conditioned our habits of perception. Reynolds felt 'Little Signs of Passion' prompted a similar recognition through its experimentation with narrative. ${ }^{11}$

This freedom to experiment was characteristic of the underground comix movement to which Spiegelman belonged. Catalysed by R. Crumb's Zap 1 (1968) and centred on San Francisco, the comix flourished until 1973. Historical accounts commonly note that the underground drew away from the institutional and representational norms of mid-twentiethcentury American comics. The comix, for instance, were sold via mail order and through record shops, alternative bookstores, and the 'head shops' selling incense sticks, psychedelic posters, and drug paraphernalia. ${ }^{12}$ Free from comics industry censorship, the comix were marketed to adult readers and offered political satire, frank sexual subject matter, autobiography, and surrealist experimentation. Comics scholar Charles Hatfield observes that by taking a publishing format 'widely associated with faceless industrial entertainment' and turning it into an expression of intensely personal and iconoclastic visions the 'underground comix ironized the comic book medium itself. ${ }^{13}$ Crumb's ironic handling of the comic book 'package' fitted his 'larger project in the late sixties, which was in effect to reclaim bygone images from American popular culture - from comics and animated cartooning in particular and invest them with new, subversive meanings.' Crumb's subversion of 'funny animal' comics was one instance of the appropriation of popular culture genres taking place across 
the underground. Hatfield reads these parodies as a deliberate gambit to turn 'spoof into a vehicle for cultural argument' but over time the comix disengaged from 'larger political issues. ${ }^{, 14}$ Before 1968 the comix were printed in underground newspapers, national satire publications, and college humour magazines, but after Zap 1 they gradually migrated to dedicated comic books. Once in their own periodicals, the comix creators were institutionally separate from other underground journalists, and the comix became increasingly preoccupied with the history and formal possibilities of the comics medium. By the mid-1970s, 'the comix revolution ended up looking less political than stylistic in nature'. While acknowledging that politically radical comix existed throughout the 1970s, for Hatfield 'what was most 'political' about [the underground comix], most effective, was simply the freedom with which they approached the comics form' ${ }^{15}$

'Little Signs of Passion' fits Hatfield's thinking about the underground in several ways. It remixes the narrative and mechanical constituents of mid-twentieth-century romance comics in a display of virtuosity that demonstrates how underground creators wrought a means of personal expression from the comic book form. The demanding technical gymnastics of 'Little Signs of Passion' was becoming Spiegelman's signature style in the mid-1970s. But this comic's formal experimentation and self-awareness of comics history was not an evasion of political issues: readers were forced to confront a newly prominent cultural form being challenged for its misogyny in the courtrooms and on the streets. Other comix creators satirised the emergence of hard-core pornography but what made 'Little Signs of Passion' different is that its playful deconstruction of the genre was a means of interrogating hardcore's sexual politics on the level of narrative structure. Furthermore, in underlining hard-core pornography's predictability, commerciality, and gender politics, Spiegelman's comic ran against the countercultural voices who praised the radical potential of pornography. 


\section{Underground comix and the politics of pornography}

Earlier writers like D. H. Lawrence considered sexual intercourse a potential force of resistance against the deadening effects of industrial society, a theme picked up by the 1960s counterculture, where ' $[\mathrm{s}]$ exual freedom was $[\ldots]$ a revolutionary demand connected to social justice'. ${ }^{16}$ The White Panther Party, for instance, called for 'Fucking in the Streets' ${ }^{17}$ in 1969 as part of their radical assault on bourgeois American culture. When 'Little Signs of Passion' was first published more Americans were viewing pornography than ever before and sociologist Sam Binkley suggests this 'insurrectionary sexual culture' was so popular it threatened 'the taste hierarchy of the old middle-class culture'. ${ }^{18}$

Historians have seen the 'expansion of the pornography industry in the 1970s' as 'a marketplace manifestation of the sexual revolution' ${ }^{19}$ which countercultural voices had called for in the 1960s. There was clear crossover between the New Left, the counterculture, and the pornography boom, with some underground newspapers becoming outright 'pornzines' ${ }^{20}$ One sexually explicit publication was Screw, founded by Al Goldstein and underground newspaper editor Jim Buckley in 1968, which contained contributions from prominent feminists such as the journalist Leah Fritz. These writers initially believed that Screw 'supported the ideals of the Left' but Fritz quit after 'an onslaught of vicious pictorial and verbal attacks on women'. ${ }^{21}$ When Buckley and Goldstein were charged with distributing pornography the journalist Leo Skir defended the magazine in the Evergreen Review as a symbol of free expression, but he was conflicted about the nature of Screw's contribution to the cause of liberation (a quotation from Skir's article was reproduced in Schneider and Spiegelman's Whole Grains). ${ }^{22}$ In 1972 hard-core cinema-going became a fashionable leisure pursuit for the hip middle class in America's major cities but pornography's increased popularity prompted intense debates about the gendering of sexual pleasure and power. 
At the start of the twentieth century American sex films were silent, black and white, short, and lacking complex - or even coherent - narratives. These illegal 'stag films' were anonymously made and shown in exclusively male social settings. ${ }^{23}$ US adult cinemas first exhibited sexual penetration in 1970 and, from that moment on, hard-core pornographic filmmaking moved towards Hollywood's norms: feature-length duration, psychologically credible characters developed through dialogue, narrative storytelling, and the use of a star system of directors and performers to market film texts. ${ }^{24}$ The 1972 release of Deep Throat (dir. Gerard Damiano) attracted striking publicity and impressive box office takings and its use of the money shot popularised a technique that became ubiquitous in pornographic films as a signifier that an episode of sex has reached its endpoint. In Deep Throat the main character (played by Linda Lovelace) cannot orgasm because her clitoris is in her throat; once she learns this, she develops the 'deep throat' fellatio technique, leading to a money shot and her much anticipated climax. ${ }^{25}$ Laurence O'Toole's book Pornocopia (1998) asserts 'Deep Throat was right on time. A newly sexually enlightened and sexually vigorous America was gagging for $[\ldots]$ the learning of the technique of the blow job, for the witnessing of such exotic oral entertainments'. ${ }^{26}$ During the film's obscenity trial a prosecution witness said that if the fellatio scenes 'were taken out of the movie, there would be no movie left and certainly no reason for seeing it'. ${ }^{27}$ Other hard-core films made more money but Deep Throat occupied centre stage as pornographic movies transitioned from 'illicit' shorts to 'legal, fictional narratives'. It attracted unprecedentedly large and diverse audiences and made $\$ 3.2$ million by January $1973 .^{28}$

The film's popularity and financial success 'provoked a high-profile clash between women who despised pornography and men who celebrated it as a social good'. For the latter Deep Throat celebrated a woman's right to sexual pleasure, 'a tale of equal opportunity made possible by the sexual revolution'. But across the United States the film and its successors 
were denounced for being misogynistic, dull, and for endangering female actors while male filmmakers and exhibitors earned small fortunes. ${ }^{29}$ In The New York Review of Books Ellen Willis reviewed Deep Throat as the 'consumerist version' of the 'sexual revolution', one which adopted a masculine perspective and catered to male 'fantasies on a mass scale'. ${ }^{30}$ Historian Carolyn Bronstein writes that:

pornographers (and in some cases, activist men in the New Left) marketed male sexual entitlement with supreme confidence and force, and depicted women as willing, panting, mindless objects ripe for male abuse. For women who had embraced the idealism of the sexual revolution [as a] route to social transformation, such treatment was a betrayal. ${ }^{31}$

Grassroots feminist organisations such as Women Against Pornography (WAP) sprang up, with WAP cofounder Susan Brownmiller protesting that pornography was a 'male invention [...] designed to dehumanize women, to reduce the female to an object of sexual access' ${ }^{32}$

Similar arguments were taking place in the comix community at the same moment. Explicit sexual content, sometimes combined with violence, was widespread, and these representations 'often left unexamined received ideas of the role of women'. ${ }^{33}$ On one level this was testament to the desire of underground creators to transform the comic book into a medium for uninhibited individual expression; the orgies, fetishes, and severed penises signified that the only cap on what (male) artists could draw and publish was their own imagination. ${ }^{34}$ There were economic reasons too, and the artist Robert Crumb commented that sex comics 'really sell. [...] People are hot about sex. Anything they can get'. ${ }^{35}$ In 1974 underground journalist Mary McKenney asserted that the burgeoning women's and gay comix were a desirable counterpoint to the 'machismo of R. Crumb' and other male creators. ${ }^{36}$ McKenney was responding to the establishment of female comix collectives such as the Wimmen's Comix Collective and Nanny Goat Productions, and women's comix often 
advocated feminist agendas: for instance, Abortion Eve (1973) and Mama! Dramas (1978) were dedicated to reproductive rights and motherhood respectively. Female creators objected to the torrent of rape and murder directed against women in the comix and in April 1973 Bill Griffith criticised the underground's thoughtless sexism in a letter to the San Francisco Phoenix, prompting other creators to write in and defend their work. ${ }^{37}$ Griffith's mini-comic Young and Lustless (undated but probably published c.1973-74) derided the underground's sexist formulae:

Have you 'Had it up to here' with all the male-orientated sex fantasies and gratuitous violence so typical of today's 'comix books'? Are you 'sick unto death' when you see the total lack of political savvy or even good old-fashioned 'social consciousness' these creeps display ${ }^{38}$

As this shows, by the time 'Little Signs of Passion' appeared in Young Lust 4 (1974), an anthology comic edited by Griffith and Jay Kinney, the comix movement was vocally divided over the gender politics of drawing nudity and sex.

At this time Spiegelman was recalibrating his own trajectory as a comic creator. In the 1960s his psychedelic comix explored surreal worlds, fantastical creatures, and nonsense verse, with obvious affinities to acid-trip narratives. ${ }^{39}$ Around 1970 , like so many underground creators influenced by Crumb's jettisoning of self-censorship, Spiegelman began to combine sex and violence in calculatedly shocking ways. ${ }^{40}$ Perhaps influenced by his friend Griffith's public comments, Spiegelman took a revolutionary step forward in the mid-1970s and he used his comics to conduct a series of experiments exposing and undoing the formal and narrative structures of various mass media forms, including soap operas, detective fiction, and newspaper strips. These comics, challenging readers' patience and cognitive dexterity, were primarily published in Arcade: The Comics Revue (1975-76), an anthology edited by Spiegelman and Griffith. 
'Little Signs of Passion' is an early example of this fertile phase in Spiegelman's career. One underground journalist reported Young Lust being sold 'as porn [...] in adult bookstores', ${ }^{41}$ but while 'Little Signs of Passion' could undoubtedly be pored over for the purpose of prurient gratification, Spiegelman used sexually explicit images to intervene in debates about pornography and gender politics. Far from commending the normalisation of pornography as a victory for the destruction of inhibition, 'Little Signs of Passion' elaborated hard-core film's boundedness to predictable narrative conventions, posing one of those conventions as a fixation on masculine anxiety about the phallus.

\section{Hard-core feature films, romance comics, and popular narrative}

'Little Signs of Passion' was unusual for an underground comic since it was printed in full colour. Most of the panels evoke the visual look of comics from the 1940s and 1950s, bold colours delivered in blocks of homogeneous tone. Young Lust's title alluded to Joe Simon and Jack Kirby's pioneering comic Young Romance (1947-77), launched to reproduce the popularity of the 'love pulps' and 'slick' confession magazines. Young Romance eventually sold over a million copies per issue and instigated a boom in romance comics peaking in 1952. These comics 'could only vaguely hint' at 'sexual activity' and were dominated by the plot template 'girl finds love through boy's wisdom after girl makes serious mistake and nearly loses boy'. ${ }^{42}$ Despite Spiegelman's evocation of mid-twentieth-century romance comics, 'Little Signs of Passion' is located squarely in the 1970s by the poster (the first sign the reader sees, in a story whose title foregrounds their presence) outside the Roxie cinema advertising a 'Hard-core feature and full-color action shorts' ${ }^{43}$ Presumably these 'action shorts' are the films known at the time as 'action beavers', a subset of the short 'beaver films' displaying female genitalia. ${ }^{44}$ There can be no doubt that 'Hard-core feature' refers to a feature-length pornographic film. 
These two representational modes - 1970s hard-core pornography and mid-century romance comics - are juxtaposed at the top of the first page (Figure 1). On the right is what looks like a shot from a hard-core film and on the left is an introductory caption ${ }^{45}$ above a series of panels:

Well there is Marsha and she is a midget and sits in the glass booth of the Roxie and sells tickets.

And well there is Augie and he paints signs in a shop up the street and Augie is a dwarf.

And that is all there is to it except for Foul Bernie the Gimp. He is foul when he is drunk and he is always drunk, so he is called Foul Bernie.

As Kartalopoulos notes, Spiegelman draws attention to the mechanical production of comics (the characters are assembled by adding successive layers of colour, a reference to the colour separation plates used in printing) and the romance genre (the red hearts dotted around Marsha and Augie programme the reader to expect them to fall in love). Kartalopoulos reads the juxtaposed images in terms of generic difference, namely how the left-hand panels propose the potential for romantic coupling, whereas the right-hand image implies how an alternative genre might visualise a different kind of union. ${ }^{46}$ The shot from the pornographic film is drawn in black-and-white un-inked pencils, with veins and folds of skin picked out, and while one should be careful about declaring this a realistic style - Spiegelman scholar Joseph Witek reminds us that realism is 'a conspiracy between writer and reader, not an essential relation between certain texts and the world of experience ${ }^{47}$ - perhaps it is permissible to say that this black-and-white style is more realistic than the blocks of bright colour adopted for the romance plot. Slavoj Žižek's (deliberately disingenuous) comments on pornography come to mind, that it is "the genre supposed to "show everything," to hide nothing, to register "all" with an objective camera and offer it to our view'. ${ }^{48}$ Also in play are 
a set of assumptions inherited from Hollywood cinema, where, until the mid-1960s, colour was used to augment a film's spectacular, dramatic elements. Colour clashed with 'Hollywood's particular understanding of realism' so it was notably used for 'fantasy movies' and musicals. ${ }^{49}$ The opening of 'Little Signs of Passion' elaborates an opposition between the 'contrived [...] fantasies' 50 of romance comics (whose wholesome love only seems possible within the artificial confines of the comic book) and the raw sexuality of hard-core pornography (where the explicitness, detail, and texture of Spiegelman's drawing aspire to the verisimilitude promised by a film camera).

This opposition was present in Bill Griffith's comic 'They Called our Young Love Porno-Graphic! But... We Don't Care!' (1970), from the first issue of Young Lust. Dubious of the progressive claims made for the sex film industry Griffith indicates that women regularly take subordinate or masochistic roles (a female character is filmed saying 'humiliate me'). ${ }^{51}$ For Griffith the representation of sex in Young Lust was meant to be 'larger-than life, caricatured, gross [...] the flipside of the paternal, insipid Girls [sic] Romance Comics'. ${ }^{52}$ 'They Called our Young Love Porno-Graphic!' obeys the 'first law of love comics', ${ }^{53}$ a retrospective verbal narration by the female protagonist. The comedic core of this story is the incongruity between obscene images and the verbal narration following the conventions of the sexually chaste romance genre. Griffith takes aim at the immorality of the sex film industry but he also uses pornographic images to stretch and exhaust the seeming naivety of romance's conventions. Spiegelman's 'Love's Body' (1970), a one-page story about necrophilia from the same issue of Young Lust, exploited a similar tension for humorous effect. $^{54}$

'Little Signs of Passion' takes this impulse towards caricature and joins it to a more complicated mode of narration. One facet of its parody is the thrice-told love story, inviting readers to laugh at the predictability of the romance genre's stock plot. In the bottom half of 
the first page, the words from the opening caption (the inset quotation above) are repeated in the past tense, accompanied by a six-panel comic in which Foul Bernie walks past a row of shops. He knocks over a can of red paint outside Augie's sign shop and the contents pour down the street. The comic then re-runs an almost identical scenario ${ }^{55}$ extended to two pages, showing the spilt paint running past Marsha's booth. Kartalopoulos comments that the panel in which Bernie knocks over the can, marked by the slippage of the colour plates (Figure 2), underlines the artificiality of the narrative. Imbricating Bernie's trip and the slipping plates is a reminder that most comics are the product of mechanical printing technology - and equally mechanical narrative formula, since the spilt paint, running from Augie's shop to Marsha's booth, promises to unite them romantically. ${ }^{56}$

The final, longest version of this story contains extracts from screenwriter and novelist Jack Woodford's 1933 book Trial and Error: A Key to the Secret of Writing and Selling. These quotations assert that a successful romance narrative must feature a 'complication' throwing into doubt the successful resolution of the dynamic between male and female characters. Even though the reader 'knows perfectly well that the pair will marry' they worry about the 'complication' and latent sadism means readers 'become restless' if the 'course of true love runs smoothly'. In a passage that does not appear in Spiegelman's comic, Trial and Error proclaims the profitability of Woodford's narrative model: 'There is only one love story. It has been written over and over for generations, and it will probably be salable [sic] for more generations'. ${ }^{7}$ 'Little Signs of Passion' tells a story in words, tells it again in six panels, and tells it once more in twenty-four panels; by finishing the comic the reader proves Woodford right, since we know how the narrative concludes and yet we repeatedly read essentially the same story. The change from the present tense to past tense when the story is first repeated reiterates this: what we are reading is happening now (we see the 'present' inside each panel of the story) but it also happened then (in the opening 
description). This love story has always already happened because it is embedded in the narrative structures of popular storytelling. ${ }^{58}$

In the above reading 'Little Signs of Passion' contrasts the simplistic predictability of mass-produced romance comics against the shocking explicitness of hard-core pornography. But what immediately appears as contrast is really comparison. Spiegelman sensed that pornography was becoming more, not less, like other forms of popular narrative media: hardcore had 'joined the entertainment mainstream'. ${ }^{59}$ The last telling of the love story in 'Little Signs of Passion' begins with three black-and-white panels that continue the sex scene from the first page. In the third of these panels the female performer is partially obscured by Bernie standing up to leave his seat (Figure 3), confirming that we are looking at a film being projected inside the Roxie. These monochrome images do not represent an external reality against which we may judge the conventions of romance comics; the black-and-white panels are folded inside the fictional four-colour world and the pornographic film is just as artificial and constructed. Later, in the comic's final black-and-white panel (Figure 4), Spiegelman pairs a shot of fellatio with this Woodford quotation: 'You have teased the reader a bit about this. And then had your two characters sure enough fall in love'. The woman in the film has been on the verge of sucking her co-star's penis for 13 panels, and that too is an act of dramatic suspense worthy of the 'complication' Woodford writes about. As with Woodford's description of the romance reader's confidence in the outcome of dangling narrative threads, hard-core narrative (as early as 1974) had trained audiences to know where scenes of heterosexual coitus were leading. 'Fellatio - culminating in a money shot in which ejaculation occurs on the woman's face and mouth - becomes, in the wake of Deep Throat's enormous popularity, the privileged figure for the expression of climax and satisfaction' ${ }^{60}$ In 'Little Signs of Passion' Woodford's theory that successful popular narratives depend upon the pleasures of expectation piqued and fulfilled is proved accurate for both romance and 
hardcore. By quoting Woodford and verbalising the plot conventions of romance comics, 'Little Signs of Passion' illuminates the symbolic function of fellatio as a signpost within the narrative system of feature-length hard-core pornography. Fellatio and the subsequent money shot were not spontaneous affirmations of the desires denied by American capitalist society. Hard-core films were regulated by conventions of popular narrative that had proven useful in other genres as a means of cultivating consumers' expectations.

\section{The visibility of the phallus}

Al Goldstein, co-publisher of Screw and porn film critic, gave Deep Throat a rave review. He praised 'the greatest on-screen fellatio since the birth of Christ' and the consequent money shot: 'the climactic moment I was poised and ready for appeared! Hot white cum shot out'. ${ }^{61}$ Goldstein was quoted in trade advertisements, on the back of the film's novelisation, and Screw devoted a four-page spread to Linda Lovelace. ${ }^{62}$

Spiegelman knew of Goldstein's delight in the exhibition of penile tumescence, reproducing his assertion 'An erection is a beautiful thing' on page 22 of Whole Grains. Those words first saw print in Leo Skir's 1971 Evergreen Review article, which appeared when Screw's publishers were awaiting trial for printing a photograph deemed to show an aroused penis. Goldstein was unrepentant: 'if I saw a picture of an attractive hardon I'd print it. [...] An erection is a beautiful thing'. ${ }^{63}$ The visible presence of an erect penis in an act of 'genital, oral, or anal' penetration distinguished hard-core features from contemporaneous 'simulation' ${ }^{64}$ films and the erection in Screw led to criminal charges for promoting hard-core obscenity. ${ }^{65}$ In 1974 Spiegelman would have known that the rapid (though contested) acceptability of erect, fellated penises on film marked a decisive change in the history of pornography. 'Little Signs of Passion' does not depict ejaculation, but it depicts the fellatio 
frequently leading up to it, and Spiegelman's comic debates the psychological work that scenes like this are doing.

Pornography scholar Linda Williams reads the money shot as a way of luxuriating in male orgasm:

[The] money shot offers a real penis substituting for the mythic phallus Freud's little boy fears to have lost. Indeed, these close-ups of remarkably long, perpetually hard, ejaculating penises might seem to be literal embodiments of this idealized fantasy phallus which Freud says we all - men and women - desire. The ejaculating penis of the money shot could, in this sense, be said to disavow castration by avoiding visual association with the woman's genitalia. ${ }^{66}$

The pleasure of 'the straight male viewer' would be contaminated if the penis ejaculated inside female genitals, which signify the possibility of castration. Such viewers are assured by the money shot that the vagina 'has once again yielded its victim [i.e. the phallus]' ${ }^{67}$ Since 'some men are unmanned by the loss of boundary that sex entails', withdrawing and ejaculating on the woman's body 'marks her as separate' and preserves a 'detached and bounded sexual identity'. ${ }^{68}$

The fellatio panels in 'Little Signs of Passion' never reach the point where withdrawal and ejaculation establish a 'detached and bounded sexual identity', all the more reason for the porn-watching (and prominently peg-legged) Bernie to find another way to assert female lack, via a dirty joke:

I walked past some broad yesterday. It was real windy! ... so de wind blows her skoit up over her waist and she ain’t got no underpants on!... ... so she sees me staring at her twat and she sez, 'I kin see as you ain't no gennleman!' [...] So I sez to her, I kin see as you ain't no gennleman neither! Hyar! Hyaw! 
Spiegelman's 1975 comics-essay 'Cracking Jokes: A Brief Inquiry into Various Aspects of Humor', reprinted in Breakdowns, featured Sigmund Freud and reminded readers that the 'castrated father figure is at the base of much comedy' ${ }^{69}$ Freud's Jokes and their Relation to the Unconscious (1905) mooted various drives behind the smutty joke; (class) hostility and 'sexual aggressiveness' seem most relevant to Bernie. ${ }^{70}$ In the analysis offered by porn scholar Laura Kipnis the dirty jokes in Hustler magazine also pivot on the confounding of 'uptight class refinement' ${ }^{71}$ Bernie, whose exaggerated speech implies he is working class, derives amusement from undermining female propriety, and thus (in the words of Freud) his 'tendentious joke' releases 'pleasure even from sources that have undergone repression': Bernie can laugh at castration when the target of his gag is upper-class women's 'incapacity to tolerate undisguised sexuality ${ }^{72}$ and he buttresses his sexual selfhood by contrasting his identity against the visual evidence of the woman's genitals.

The danger of bringing Spiegelman's interest in Freud into an examination of Bernie is that Bernie could appear as a psychologically credible human being. He isn't. His role is to direct our attention to the gender politics of hardcore. Why else do we see Bernie fastening his trousers as he leaves the Roxie? By 1974 it was unusual to find solitary male masturbators in adult cinemas. ${ }^{73} \mathrm{We}$ are shown Bernie closing his flies because this character is essential to Spiegelman's critique. The masturbating Bernie stands for the viewing position that 1970s hard-core films flattered, a 'male consumer' whose 'castration fear' leads him to fetishize the money shot. ${ }^{74}$ Elsewhere in Breakdowns Spiegelman's comic 'Real Dream' (originally published in 1974) also connected the consumption of pornography (owning a copy of Playboy) to the display of the phallus and the securing of heterosexual masculine identity. ${ }^{75}$ In 'Little Signs of Passion' Marsha sits silently outside the cinema, not because women did not watch hardcore in the early 1970s, but because their voices and pleasures were of secondary importance in the making of these films. Bernie's actions and words hint at 
hardcore's function for heterosexual male spectators, buttressing an uneasy sense of masculinity predicated on the anxious hope of possession of the phallus and the social capital it promises.

Spiegelman knew that comics, underground comix especially, shared the gendering of spectatorship that structured hard-core filmmaking. Breakdowns's one-page introduction visually quotes from 'Little Signs of Passion' so that two images from adjacent panels Bernie zipping up his flies and Augie painting a sign - are repeated for the reader's perusal. A conversation between the images is apparent: framed as if Augie's hand is Spiegelman's own entering from outside the diegesis and inking the panel with a brush, the gendered pleasures of hardcore appear to have a corollary in the products made by the male comix creator. Even the 'zip' of Bernie's trousers points to the zip-a-tone sheets used to make comics, the latter the basis for Spiegelman's experimentation in Zip-a-Tunes and Moiré Melodies, a minicomic from 1972 reprinted in Breakdowns. ${ }^{76}$ Spiegelman directly implicated himself in the final text in the collection, 'Ace Hole, Midget Detective' (1974). This story stars a 'small change underground cartoonist' called Al Floogleman who produced sexually explicit comix earlier in his career; 'Floogleman' was one of Spiegelman's pseudonyms. ${ }^{77}$

Fellatio and the money shot are visually rhymed throughout Breakdowns but, as with 'Little Signs of Passion', the other comics in the collection consistently deny the phallic presence and disavowal of castration that Linda Williams attributed to hardcore's most iconic set-piece. For example, in the 1974 'Real Dream' comic the Spiegelman character is about to be fellated in a toilet cubicle when cops burst in, preventing the act from taking place. Floogleman enters the narrative of 'Ace Hole, Midget Detective' as a murder victim; far from being the wielder of phallic certitude, this former creator of pornographic comix has a bullethole in his forehead and the blood bears a noticeable resemblance to ejaculate. Most important is the cover and front matter of Breakdowns, which show Spiegelman's avatar at 
the drawing board, head tilted back, quaffing a stream of ink with a distinct phallic thickness. This image is repeated across the cover and endpapers in different permutations as the colour separation sheets are placed out of alignment or at the wrong angles. The overall effect is a series of dazzling chromatic quick changes where the outlines of objects stutter and the Spiegelman character disappears, reappears, and hovers in spectral form. It is as if Spiegelman was determined to take vengeance on the figure of the male underground comix creator, subjecting him to a poetic fate: the purveyor of sexualised images becomes the fellator. The underground creator compulsively consumes the tools of his trade in a concatenation of panels that, far from confirming the phallic power of his implements, renders his presence and identity as nothing more or less than the effect of mechanical production, prone to slips which erase the figure of the artist in the process. This reaches its paroxysm on Breakdowns's title page, where the ink gushes out and virtually obliterates the artist from sight.

It's an experiment that testifies to Spiegelman's fascination with repetition as a creative act, a fascination that structures the narrative circularity of 'Little Signs of Passion', with its recurring image of red paint spilling over the pavement. Indeed, this image is important enough to have the comic's (figurative) last word, running off the bottom of the final page and rupturing the hyperframe ${ }^{78}$ (Figure 5). The prominence of the paint leads us back to romance comics, but not to dismiss the older genre as outdated and irrelevant. Spiegelman does compare hard-core films to romance comics in order to undermine hardcore's purported radicalism, but we should read the red paint in 'Little Signs of Passion' as an ode to the romance genre's visual codes.

\section{Signs of irony, signs of love}


In its commitment to the iconographic legacy of romance comics 'Little Signs of Passion' is rather different from other underground romance parodies. Hatfield observes that women's comix frequently subverted the genre's conventions in the service of feminist critique, lampooning the genre for its heteronormativity and impossible standards of female beauty and propriety. ${ }^{79}$ Underground creator Roberta Gregory's coming-out tale 'A Modern Romance' (1974) alludes to comics like Modern Love (1949-50) but re-signifies modern romance as something no longer exclusively heterosexual. ${ }^{80}$ Like Young Lust the underground series Manhunt (1973-74) caricatured romance comics and confessional story magazines with exaggerated versions of covers, advice columns, and advertisements. Female and male creators produced stories of threesomes and drug-taking, combining romance conventions with socially transgressive subject matter to draw attention to "the superficiality and artifice of romance comics ${ }^{\prime 81}$ and the genre's gender ideologies. The overriding quarry of the romance parodies was the positing of heterosexual, monogamous marriage as right and necessary, as seen at the start of T. S. Richards's 'Can This Marriage Be Destroyed?' (1973), where the once-married female protagonist declares 'I was a victim of outmoded social convention!!' ${ }^{82}$

While most underground parodies thought the archaism of romance conventions deserved to be mocked, Spiegelman disagreed. Comics historians contend that 'love comics were not as generic as people today believe' 83 and Michelle Nolan conjectures that comics fans in the 1970s dismissed 'romance comics as repetitious, banal and generally less interesting' because of an implicit gender dimension: the audience for romance comics was overwhelmingly female while comics fans 'were mostly males'. ${ }^{84}$ Is Spiegelman guilty of this superciliousness? 'Little Signs of Passion' does assume that romance comics are governed by repeated narrative structures but Spiegelman is also out to celebrate the visual 
codes of the romance genre, implying they are powerful and thrilling, even after one learns how they operate.

In order to show this, we must return to Jack Woodford's influence on Spiegelman, who described the former as 'a great writer about writing'; ${ }^{85}$ Woodford is quoted on pages 4 , 8-9, 13 and 15 of Whole Grains accordingly. Woodford wrote for many different markets, including 'smooshes' (sex story magazines) and 'sex pulps' (titillating popular novels) ${ }^{86}$ In Trial and Error he argued that behind 'every love story there is [...] the thought of sex. It is all sex, in symbolical, rationalized form'. Woodford advised against the direct treatment of sex if writers wanted to find success in mass-market fiction: any 'drive toward sexual expression' must 'take on all manner of disguises and symbolical interpretations'. ${ }^{87}$ As comics scholar Jeanne Emerson Gardner notes, mid-century romance comics had 'to reflect the choices and priorities of the young people who were buying them' while appeasing selfappointed guardians of public morality who 'scrutinized' them for 'sexual suggestiveness' ${ }^{88}$ Able only to 'vaguely hint' ${ }^{89}$ at sexual activities, these comics used 'disguises' such as those that featured on the covers of Young Romance during the 1950s: a woman brandishing a halfeaten apple, coffee splashing across a lunch counter (looking very much like Spiegelman's red paint), and a pussy stroked in wanton fashion. ${ }^{90}$

In 'Little Signs of Passion' the bottom row of each page contains a panel in which a knocked-over paint can is the centre of the composition (Figures 6a, 6b, and 6c). When the story that took place on page one is rerun on pages two and three, the panels focusing on the spilt paint do not fit into the temporal continuity. While the panel on page three could conceivably be located in time between the panels on either side of it, the panel on page two shows the paint spilling out before the can is knocked over. Kartalopoulos sees the out-oftime paint spillage pre-empting the story's end, sabotaging the suspense that narrative feeds off and a permutation of the comic's insistence on its own repetitiveness. ${ }^{91}$ I think the 
multiple chronologies in 'Little Signs of Passion' are also illustrating a point about the enduring sexual symbolism of the romance genre. Because of their position on the page and almost identical composition these three panels can be read as constituting a distinct 'series' ${ }^{\text {'92 }}$ sitting outside the comic's linear sequence of panels. I read the latter two panels in this series as a continuation of the paint spillage from the first page, with the spilt paint an example of the romance genre's sexual symbolism, one of those 'disguises and symbolical interpretations' that Woodford identified; this symbol bleeds off the last page, pointing up the life it enjoys beyond any individual text.

Kartalopoulos believes Marsha misinterprets the red trickle as blood and that readers share her shock despite their knowledge it is only paint. ${ }^{93}$ This is difficult to prove, but one can certainly be emotionally invested in a scene whilst being conscious of its narrative mechanics, or in Spiegelman's words, 'I like the idea of telling you how a magic trick is done and still making it seem like magic when you see it. ${ }^{94}$ His comic is a little sign of passion, a small act of Spiegelman's love for the romance genre, and its visual and narrative codes cannot be easily wiped from the sidewalk, even after the reader learns how they operate. 'Little Signs of Passion' keeps faith with these symbols, attesting to their expressiveness and longevity.

Spiegelman's juxtaposition of pornographic film and romance comics feints to assert the shocking rawness of the former and the mechanically produced predictability of the latter, but by the end of this encounter hardcore looks entirely conventional and its narrative markers (fellatio and the money shot) are revealed to be fixed on masculine pleasures and anxieties. With this comic Spiegelman took the underground's obscenity and formal experimentation into new areas of complexity that related to ongoing public debates, signalling a transformation in his creative practice. 'Little Signs of Passion' assumes that romance comics are fundamentally repetitive but its tone is not sneering cynicism. 
Spiegelman strips the genre down to its narrative skeleton because, in seeing it with greater clarity, we admire its 'magic' all the more.

\section{Acknowledgements}

My thanks to Joseph 'Rusty' Witek for his help in strengthening this work at earlier stages in its development.

This work was supported by the Arts and Humanities Research Council under Grant $\mathrm{AH} / \mathrm{L} 00965 \mathrm{X} / 1$; and the Eccles Centre at the British Library [no grant number available]. 
${ }^{1}$ The spelling 'comix' distinguishes 'the irreverent and iconoclastic self-published black-and-white comic books often associated with the Sixties counterculture from their mainstream, four-color, corporately produced cousins.' Joseph Witek, 'Imagetext, or, Why Art Spiegelman Doesn't Draw Comics', ImageTexT: Interdisciplinary Comics Studies, 1.1 (2004).

http://www.english.ufl.edu/imagetext/archives/v1_1/witek/ [Date accessed: 16 June 2017].

${ }^{2}$ D. H. Lawrence, 'Pornography and Obscenity', in Michael Herbert (ed.), Selected Critical Writings (Oxford: Oxford UP, 1998), pp. 294-313 (p. 294).

${ }^{3}$ I am defining 'pornography' as texts produced for the purpose of sexual gratification through the display of human bodies and 'hard-core pornography' as the explicit depiction of penetrative sexual acts.

${ }^{4}$ See Hillary Chute, “"The Shadow of a Past Time”: History and Graphic Representation in Maus', Twentieth-Century Literature, 52.2 (2006), pp. 206-8; Marianne Hirsch, 'The Generation of Postmemory', Poetics Today, 29.1 (2008), pp. 103-28; Andreas Huyssen, 'Of Mice and Mimesis: Reading Spiegelman with Adorno', New German Critique: An Interdisciplinary Journal of German Studies, 81 (2000), pp. 72-4; Joseph Witek, Comic Books as History: The Narrative Art of Jack Jackson, Art Spiegelman, and Harvey Pekar (Jackson, MS: University Press of Mississppi, 1989), pp. 96-120. Jared Gardner considers 'Prisoner on the Hell Planet' and 'Maus' in relation to Maus and autobiography but goes further back to Spiegelman's 1960s comics too. Gardner, Projections: Comics and the History of Twenty-First-Century Storytelling (Stanford: Stanford University Press, 2012), pp. 123-4, 137-41.

${ }^{5}$ Eugene P. Kannenberg, Jr., 'Form, Function, Fiction: Text and Image in the Comics Narratives of Winsor McCay, Art Spiegelman, and Chris Ware’ (PhD diss., University of Connecticut, 2002); Bill Kartalopoulos, 'Comics as Art: Spiegelman's Breakdowns,' Indy Magazine, Winter 2005.

http://www.web.archive.org/web/20080622142420/64.23.98.142/indy/winter_2005/breakdowns/index html [Date accessed: 16 June 2017]; Philip Smith, Reading Art Spiegelman (New York: Routledge, 2016).

${ }^{6}$ Art Spiegelman, Breakdowns (New York: Bélier, 1977).

${ }^{7}$ Kannenberg, 'Form, Function, Fiction', p. 128.

${ }^{8}$ Bella Brodzki, 'Breakdowns and Breakthroughs: Looking for Art in Young Spiegelman,' in Michael A. Chaney (ed.), Graphic Subjects: Critical Essays on Autobiography and Graphic Novels, (Madison, WI: University of Wisconsin Press, 2011), pp. 51-8 (p. 52).

${ }^{9}$ Michael Reynolds, 'Cinemanic', Berkeley Barb, 4-10 April 1975, p. 17.

${ }^{10}$ Art Spiegelman, Breakdowns: Portrait of the Artist as a Young \%@ [squiggle]*! (London: VikingPenguin, 2008).

${ }^{11}$ Reynolds, 'Cinemanic', p. 17. 
${ }^{12}$ Patrick Rosenkranz, Rebel Visions: The Underground Comix Revolution 1963-1975 (Seattle: Fantagraphics, 2008).

${ }^{13}$ Charles Hatfield, Alternative Comics: An Emerging Literature (Jackson: University Press of Mississippi, 2005), pp. 7-11.

${ }^{14}$ Hatfield, Alternative Comics, pp. 11-9.

${ }^{15}$ Hatfield, Alternative Comics, pp. 19-20.

${ }^{16}$ Carolyn Bronstein, Battling Pornography: The American Feminist Anti-Pornography Movement, 1976-1986 (New York: Cambridge University Press, 2011), pp. 26-8.

17 'White Panther Party Statement', Berkeley Barb, 28 March - 3 April 1969, p. 3.

${ }^{18}$ Sam Binkley, Getting Loose: Lifestyle Consumption in the 1970s (Durham, NC: Duke University Press, 2007), p. 172.

${ }^{19}$ Bronstein, Battling Pornography, p. 65.

${ }^{20}$ John McMillan, Smoking Typewriters: The Sixties Underground Press and the Rise of the Alternative Media in America (New York: Oxford University Press, 2011), p. 175.

${ }^{21}$ Bronstein, Battling Pornography, p. 78.

${ }^{22}$ Leo Skir, 'Filth for Freedom?', Evergreen Review, January 1971, pp. 20-2; Art Spiegelman and Bob Schneider (eds.), Whole Grains: A Book of Quotations (New York: Douglas Links, 1973), p. 22. ${ }^{23}$ Linda Williams, Hard Core (Berkeley: University of California Press, 1999), pp. 60, 74.

${ }^{24}$ Laurence O'Toole, Pornocopia: Porn, Sex, Technology and Desire (London: Serpent's Tail, 1998), pp. 71-7; Kenneth Turan and Stephen F. Zito, Sinema: American Pornographic Films and the People Who Make Them (New York: Praeger, 1974), p. 124; Jon Lewis, Hollywood v. Hard Core: How the Struggle over Censorship Saved the Modern Film Industry (New York: New York University Press, 2000), pp. 209-15; Paul Willeman, 'For a Pornoscape,' in Pamela Church Gibson (ed.), More Dirty Looks: Gender, Pornography and Power (London: BFI, 2004), pp. 9-26 (p. 19).

${ }^{25}$ Williams, Hard Core, pp. 100-11.

${ }^{26}$ O'Toole, Pornocopia, pp. 71-2.

${ }^{27}$ Qtd. in Richard Smith, Getting Into Deep Throat (Chicago: Playboy, 1973), p. 128.

${ }^{28}$ Williams, Hard Core, pp. 98-99. See also Lewis, Hollywood v. Hard Core, pp. 211-2; Turan and Zito, Sinema, p. 145.

${ }^{29}$ Bronstein, Battling Pornography, pp. 79-82.

${ }^{30}$ Ellen Willis, Rev, of Deep Throat, The New York Review of Books, 23 January 1973, p. 23.

${ }^{31}$ Bronstein, Battling Pornography, pp. 65.

${ }^{32}$ Susan Brownmiller, Against Our Will: Men, Women and Rape (New York: Simon and Schuster, 1975), p. 394.

${ }^{33}$ Joe Sutliff Sanders, 'Theorizing Sexuality in Comics,' in Paul Williams and James Lyons (eds.), 
The Rise of the American Comics Artist: Creators and Contexts (Jackson: University Press of Mississippi, 2010), pp. 150-63 (pp. 156-7).

${ }^{34}$ Sanders, 'Theorizing Sexuality in Comics', pp. 156-7.

${ }^{35}$ Robert Crumb, 'Crumb Raps,' in D. K. Holm (ed.), R. Crumb: Conversations (Jackson: University Press of Mississippi, 2004), pp. 3-5 (p. 5). See also Jean-Paul Gabilliet, Of Comics and Men: A

Cultural History of American Comic Books, trans. by Bart Beaty and Nick Nguyen (Jackson:

University Press of Mississippi, 2010), p. 81.

${ }^{36}$ Mary McKenney, 'MIND CANDY for the Ms's', Booklegger Magazine, September-October 1974, pp. 17-19 (p. 17).

${ }^{37}$ Trina Robbins, From Girls to Grrrlz: A History of Comics from Teens to Zines (San Francisco: Chronicle, 1999), pp. 85-92; Rosenkranz, Rebel Visions, pp. 186-8.

${ }^{38}$ Bill Griffith, Young and Lustless (c.1973-74).

${ }^{39}$ Gardner, Projections, pp. 123-4, 137-41.

${ }^{40}$ See Spiegelman's comics 'Pop Goes the Poppa', Real Pulp Comics, 1 (1971); 'The Viper: Vicar of Vice, Villainy, and Vickedness!', Bijou Funnies, 7 (1972); 'The Sub-Teen Snatch Snatch', Real Pulp Comics, 2 (1973); 'Fatty's Final Fling', Sleazy Scandals of the Silver Screen, 1 (1974); and his drawings in Bill Griffith et al., Four Sketches and a Table of Useful Information (1973). Complicating this outline, Spiegelman created 'Prisoner on the Hell Planet' and 'Maus' in the early 1970s too.

${ }^{41}$ Clay Geerdes, Comix World, 1 October 1980. Geerdes does not state which issues were being sold.

${ }^{42}$ Michelle Nolan, Love on the Racks: A History of American Romance Comics (Jefferson, N.C.:

McFarland, 2008), pp. 3-40, 50, 102.

${ }^{43}$ Art Spiegelman, 'Little Signs of Passion', Young Lust, 4 (1974).

${ }^{44}$ Eric Schaefer, 'Gauging the Revolution: $16 \mathrm{~mm}$ Film and the Rise of the Pornographic Feature,' in Linda Williams (ed.), Porn Studies (Durham: Duke University Press, 2004), pp. 370-400.

${ }^{45}$ I use 'caption' to refer to verbal text that, while contributing to a comic's meaning, is contained in a box and not meant to represent sound from the diegesis. Thierry Groensteen, The System of Comics, trans. by Bart Beaty and Nick Nguyen (Jackson: University Press of Mississippi, 2007), p. 67.

${ }^{46}$ Kartalopoulos, 'Comics as Art'.

${ }^{47}$ Witek, Comic Books as History, pp. 116.

${ }^{48}$ Slavoj Žižek, 'Looking Awry', October 50 (1989), pp. 30-55 (p. 35).

${ }^{49}$ Richard Maltby, Hollywood Cinema: An Introduction (Oxford: Blackwell, 1995), pp. 157-9. See also David Batchelor, Chromophobia (London: Reaktion, 2000), pp. 37-41.

${ }^{50}$ Nolan, Love on the Racks, p. 3.

${ }^{51}$ Bill Griffith, 'They Called our Young Love Porno-Graphic! But... We Don’t Care!', Young Lust, 1 (1970). 
${ }^{52}$ Bill Griffith, 'Afterword', in Bill Griffith and Jay Kinney (eds.), The Young Lust Reader (San Francisco: And/Or Press, 1974), pp. 125-7 (p. 125).

${ }^{53}$ Robbins, From Girls to Grrrlz, p. 63.

${ }^{54}$ Art Spiegelman, 'Love's Body', Young Lust, 1 (1970).

${ }^{55}$ Bernie exclaims 'What th-' the first time he knocks the can over and 'Fuck!' the second time.

${ }^{56}$ Kartalopoulos, 'Comics as Art'.

${ }^{57}$ Jack Woodford, Trial and Error: A Key to the Secret of Writing \& Selling (Seattle: Woodford Memorial Editions, 1980), pp. 22-3.

${ }^{58}$ Joe Sutliff Sanders reads the 'repetitive' narrative patterning of romance comics in terms of the sublimation of women's sexuality. Mastering codes of feminine propriety and successfully entering a heterosexual relationship are repeated plot conventions because they are tolerated ways in which 'a girl can find sexual fulfilment' (Sanders, 'Theorizing Sexuality in Comics', p. 155).

${ }^{59}$ Williams, Hard Core, p. 120.

${ }^{60}$ Williams, Hard Core, p. 111. Discussing the seductions of moral simplification, in 2011

Spiegelman lamented the tendency 'to always go for the sentimental money shot.' Art Spiegelman, MetaMaus (London: Viking-Penguin, 2011), p. 70.

${ }^{61}$ Qtd. in Smith, Getting Into Deep Throat, pp. 31-2.

${ }^{62}$ Lewis, Hollywood v. Hard Core, p. 214; D. M. Perkins, Deep Throat (1973; London: Roydock, 1975); Smith, Getting Into Deep Throat, pp. 17-20.

${ }^{63}$ Skir, 'Filth for Freedom?' p. 20.

${ }^{64}$ Schaefer, 'Gauging the Revolution', p. 388.

${ }^{65}$ Rosenkranz, Rebel Visions, p. 106.

${ }^{66}$ Williams, Hard Core, p. 116.

${ }^{67}$ Gertrud Koch, 'The Body's Shadow Realm,' in Pamela Church Gibson and Roma Gibson (eds.), Dirty Looks: Women, Pornography, Power (London: BFI, 1993), pp. 22-45 (p. 42).

${ }^{68}$ Anne McClintock, 'Gonad the Barbarian and the Venus Flytrap: Portraying the Female and Male Orgasm,' in Lynne Segal and Mary McIntosh (ed.), Sex Exposed: Sexuality and the Pornography Debate (New Brunswick, NJ: Rutgers University Press, 1993), pp. 111-31 (pp. 123-4).

${ }^{69}$ Art Spiegelman, 'Cracking Jokes: A Brief Inquiry into Various Aspects of Humor', Arcade: The Comics Revue, 1 (1975), 5-6. Freud is quoted on pages 11 and 18 of Whole Grains and Spiegelman has said 'there is a kind of [Jewish] diaspora culture that I embrace wholeheartedly [that includes] Einstein, Kafka, Freud, Marx'. Art Spiegelman, 'The Ephemeral Nature of Everything: A Conversation with Art Spiegelman', International Journal of Comic Art, 12.1 (2010), pp. 401-9 (p. 409). 
${ }^{70}$ Sigmund Freud, Jokes and their Relation to the Unconscious, trans. by James Strachey (Harmondsworth: Penguin, 1976), pp. 140-44.

${ }^{71}$ Laura Kipnis, Bound and Gagged: Pornography and the Politics of Fantasy in America (Durham:

Duke University Press, 1999), pp. 144-5.

${ }^{72}$ Freud, Jokes and their Relation to the Unconscious, pp. 183-5, 144.

${ }^{73}$ Schaefer, 'Gauging the Revolution', p. 386. See also McClintock, 'Gonad the Barbarian and the Venus Flytrap', p. 120; O’Toole, Pornocopia, p. 75; Williams, Hard Core, pp. 75, 120.

${ }^{74}$ Williams, Hard Core, pp. 116.

${ }^{75}$ Art Spiegelman, 'Real Dream', Short Order Comix, 2 (1974); this interpretation is made in Kartalopoulos, 'Comics as Art'.

${ }^{76}$ Art Spiegelman, Introduction, in Breakdowns; Art Spiegelman, Zip-a-Tunes and Moiré Melodies (1972).

${ }^{77}$ Art Spiegelman, 'Ace Hole, Midget Detective', Short Order Comix, 2 (1974).

${ }^{78}$ The hyperframe is the outer edge of the totality of panels on a comics page. Groensteen, System of Comics, pp. 30-1.

${ }^{79}$ Hatfield, Alternative Comics, pp. 12-6.

${ }^{80}$ Roberta Gregory, 'A Modern Romance', Wimmen's Comix, 4 (1974).

${ }^{81}$ Nolan, Love on the Racks, pp. 4, 124, 195.

${ }^{82}$ T. S. Richards, 'Can This Marriage Be Destroyed?', Manhunt, 1 (1973).

${ }^{83}$ Robbins, From Girls to Grrlz, p. 57.

${ }^{84}$ Nolan, Love on the Racks, p. 4.

${ }^{85}$ Art Spiegelman and Françoise Mouly, 'Slaughter on Greene Street: Art Spiegelman and Françoise Mouly Talk about RAW,' in Joseph Witek (ed.), Art Spiegelman: Conversations (Jackson: University Press of Mississippi, 2007), pp. 35-67 (p. 46).

${ }^{86}$ Jay A. Gertzman, Bookleggers and Smuthounds: The Trade in Erotica, 1920-1940 (Philadelphia: University of Pennsylvania Press, 2002), pp. 5, 67-73.

${ }^{87}$ Woodford, Trial and Error, pp. 114-20.

${ }^{88}$ Jeanne Emerson Gardner, "She Got Her Man, But Could She Keep Him? Love and Marriage in American Romance Comics, 1947-1954," The Journal of American Culture, 36.1 (2013), pp. 16-24 (p. 19).

${ }^{89}$ Nolan, Love on the Racks, p. 3.

${ }^{90}$ See Young Romance 66 (February 1954), 85 (December 1956-January 1957), 102 (OctoberNovember 1959).

${ }^{91}$ Kartalopoulos, 'Comics as Art'.

${ }^{92}$ My use of this term comes from Groensteen, System of Comics, pp. 146-7. 
${ }^{93}$ Kartalopoulos, 'Comics as Art'.

${ }^{94}$ Spiegelman, MetaMaus, p. 171. 